\title{
Article
}

\section{Images across Europe: The sending and receiving of sexual images and associations with interpersonal violence in young people's relationships}

Wood, Marsha, Barter, Christine, Stanley, Nicky, Aghtaie, Nadia and Larkins, Cath

Available at http://clok.uclan.ac.uk/13214/

Wood, Marsha, Barter, Christine ORCID: 0000-0001-5682-5333, Stanley, Nicky ORCID: 0000-0002-7644-1625, Aghtaie, Nadia and Larkins, Cath ORCID: 00000003-2999-6916 (2015) Images across Europe: The sending and receiving of sexual images and associations with interpersonal violence in young people's relationships. Children and Youth Services Review, 59 . pp. 149-160. ISSN 0190-7409

It is advisable to refer to the publisher's version if you intend to cite from the work. http://dx.doi.org/10.1016/j.childyouth.2015.11.005

For more information about UCLan's research in this area go to http://www.uclan.ac.uk/researchgroups/ and search for <name of research Group>.

For information about Research generally at UCLan please go to http://www.uclan.ac.uk/research/

All outputs in CLoK are protected by Intellectual Property Rights law, including Copyright law. Copyright, IPR and Moral Rights for the works on this site are retained by the individual authors and/or other copyright owners. Terms and conditions for use of this material are defined in the policies page. 


\title{
Images across Europe: The sending and receiving of sexual images (sexting) and associations with interpersonal violence in young people's relationships
}

\begin{abstract}
This article explores young people's experiences of sending and receiving sexual images and text messages (sexting) within their interpersonal relationships and the contexts in which this occurs. The article uses data from a recent Daphne funded project 'Safeguarding teenagers' intimate relationships' (STIR) involving a survey with 4,564 young people aged between 14 and 17 in a number of schools across five countries in Europe. Findings reveal that experiences of sexting vary by country and gender. The study also found that young people who reported victimisation in their relationships were more likely to have sent a sext message than those who had not. The article points to the need for a more nuanced understanding of the varied contexts and experiences around sexting in order to better develop policy, practice and education in this area.
\end{abstract}

\section{Introduction}

The phenomenon of sending / receiving sexual images has become a part of young people's lives due to the rise in use of mobile phones and in particular smart phones enabling the exchange of images (Willard, 2010). The sending/receiving of sexual images has commonly and problematically been referred to as 'sexting' and has attracted 'considerable legal, political, public, media and academic attention' (Lee and Crofts, p.1, 2015). It has been defined as the 'exchange of sexual messages or images' (Livingstone et al., 2011) and 'the creating, sharing and forwarding of sexually suggestive nude or nearly nude images' (Lenhart, 2009) through mobile phones or the internet. It is described in the Oxford English dictionary as 'The action or practice of sending or exchanging sexually explicit or suggestive messages or images electronically, esp. using a mobile phone' (OED online, 2015).

Although we have decided to use the term 'sexting' to aid brevity and consistency with previous work we acknowledge, as others have, that it is not a definition used by young people themselves (Livingstone and Görzig, 2012; Crofts et al, 2015). Throughout the article. we use the term 'young people' to refer to adolescents under the age of 18 . For our own survey, we included young people aged between 14 and 17.

There is widespread policy concern over the risks and dangers sexting can pose to young people (Livingstone and Helsper, 2009; Muscari, 2009; Ringrose et al., 2012; Ringrose and Barajas, 2011; Crofts et al, 2015). Across Europe, policy and practice in relation to sexting amongst young people is underdeveloped. At present across Europe and in the US, there can be serious legal consequences when young people send or receive sexual images as it 
may be against the law to create, transmit or possess a sexual image of a minor (Safer Internet Centre, downloaded,07/05/2015, Arcabascio, 2010; Sacco et al., 2010). The lack of legislative clarity may cause young people to refrain from reporting negative experiences as they may be arrested or charged for engaging in child pornography (Willard, 2010) and could end up on the sex offender register (Morris, 2014). However, literal interpretations of the law vary across countries and across US states. There have been cases, particularly in the US, of young people being prosecuted for such activities (Schmitz and Siry, 2011, Lee et al 2013). A report by Wolak and Finkelhor (2011) presents a typology of sexting episodes involving young people based on a review of more than 550 US cases from law enforcement agencies. In comparison, other countries such as Germany, permit non-prosecution where images have been made and distributed with the consent of the party depicted in the image (Morris, 2014).

What is unequivocal is that although sexting is not confined to young people (Gamez-Guadix et al., 2015), it is the distribution of sexual images by teenagers which has received the most sensationalist media and public attention, portraying it as a routine and alarming aspect of youth interactions (Arcabascio, 2010; Sacco et al., 2010; Morris, 2014; Ringrose et al., 2012; Crofts et al., 2015). However, in contrast to this media depiction, it remains far from clear how prevalent an activity sexting is within young people's lives and cultures and whether and how it inflicts harm.

\subsection{Incidence rates for Sexting}

A growing body of work has sought to address how common sexting is and to a lesser extent the contexts in which this occurs. Research has found very different rates, depending on age and the way sexting was defined and measured (Lounsbury et al., 2011) and differences in sampling (Ringrose et al., 2012). A recent systematic review (Klettke et al., 2014) of studies which have explored incidence rates for sending and receiving of sexual images found 12 studies (most US based) which sampled participants from the age of 10-19. The review found that incidence rates varied from 3\% to $34 \%$ for sending images and $7 \%$ to $42 \%$ for receiving images. For studies $(n=6)$ which used a randomly stratified sample, and therefore were considered nationally representative (Associated Press and MTV, 2009; Cox communications, 2009; Lenhart, 2009; Hinjura and Patchin, 2010; Mitchell et al., 2012; Rice et al., 2012), the average rate of young people sending messages was $10.2 \%$. The average incidence rate for receiving sexual images in the five studies which measured this was $15.64 \%$.

A recent study by Walrave et al (2015) based on a small sample of 217 15- to 19-year-olds found that a total of $18 \%$ of respondents had engaged in sexting in the 2 months preceding the study. A nationally representative study of sexting found that $19 \%$ of teenagers had electrically sent a nude or semi-nude pictures or videos of themselves and $31 \%$ of teens have received such a message (The National Campaign to Prevent Teen and Unplanned 
Pregnancy, 2008). In comparison Mitchell et al's (2012) US study based on a national telephone survey of 1560 young people aged 10 to 17 found much lower rates. Two and one-half percent of young participants had appeared in nude or nearly nude pictures or videos. However, this percentage was reduced to only $1 \%$ when the definition was restricted to only include images that were sexually explicit (i.e., showed naked breasts, genitals, or bottoms). Slightly more young people (7\%) reported receiving nude or nearly nude images of others; and $6 \%$ of participants said the image received was sexually explicit. However, few youth reported distributing these images.

One study absent from Klettke's review was the EU kids online survey (Livingstone et al., 2011) which included questions on the sending / receiving of sexual images. This study, which involved interviews with over 25,000 young people across 25 countries in Europe, found that $3 \%$ of the young people across Europe aged 11-16 said that they had sent a sexual image and $15 \%$ said that they had received one. Mitchell et al (2012) conclude that sexting is far from being a normative behaviour for youth. However, it is likely that the variations in rates reported reflect cultural differences, differences in the age range of the samples utilised and the timing of the research since widespread use of smart phones by young people is relatively recent.

\subsection{Conceptualisation of Sexting}

Beyond an exploration of sexting rates studies have raised a variety of factors which highlight the complexities that surround this phenomenon. Much of the debate has prioritised the possible risks involved, thus conceptualising sexting as a primarily negative childhood activity abounding with online peril and exploitation, defined by Ferro as the 'perfect storm' (p1. 2012 ).

Consequently, much of the sexting literature has sought to identify the risks and negative outcomes associated with young people's sexting. There are for example mixed concerns around the links between sexting and engaging in physical sexual acts (Temple et al, 2012). A study in the US which included 420 participants aged 12-14 found that those who had reported sexting in the past 6 months were four to seven times more likely to engage in other sexual activities such as interpersonal kissing or touching and intercourse (Rice et al, 2012). Other studies also report associations between sexting and engaging in physical sexual activity (Houck et al, 2014; Ybarra and Mitchell, 2014). Studies also report high levels of pressure for young people to send sexual images (Associated Press and MTV, 2009; Lenhart, 2009, Ringrose et al 2012). Recent reviews provide a comprehensive overview on risks and sexting (see Drouin et al., 2015; Döring, 2014).

Another key risk factor associated with sexting is the propagation of such images over which the sender has no control. Distribution of images can be used as a means of showing off 
(Ringrose and Harvey, 2015), as blackmail or in what has become known as 'revenge porn' where sexual images are shared by an ex-partner as a means of humiliation or for their own amusement (Willard, 2010; Morris, 2014). Sexts can also be taken from their original location on social network sites and uploaded to porn sites (Smith, 2012). One US study (Rice et al, 2012) found that around one third of the 606 14-18 year olds that they surveyed were not aware or did not consider legal or other risks when sexting.

However, some commentators have contended that adhering to a risk approach to understanding sexting in young people's lives is too restrictive and fails to reflect young people's own perspectives and experiences (Ringrose et al., 2012; Lee and Croft, 2015). Thus, some researchers have sought to recast the debate away from risk to a more balanced account which seeks to acknowledge the role that sexting also plays in relation to pleasure and sexual intimacy. Unfortunatey, few surveys have addressed positive motivations for sexting or included outcomes which reflect affirmative sexting experiences (Albury and Crawford, 2012).

Two studies which did provide a range of outcomes report similarly findings. The Sex and Tech survey (The National Campaign to Prevent Teenage and Unplanned Pregancy, 2008) found the most common reason for sending an image was for fun or to be flirtatious (66\% of girls, $60 \%$ of boys), $52 \%$ of girls said it was a 'sexy present' for their boyfriend, $44 \%$ of both female and male respondents said it was in response to receiving a sext from their partner, $40 \%$ of girls sent it as a joke and $34 \%$ to feel sexy. Mitchell et al (2012) also found that the vast majority of respondents (51\%) said that sexting occurred as part of a romantic relationship and $23 \%$ said it was a joke. The Sex and Tech Survey (2008) showed that the majority of young people involved in sexting reported it as a positive experience: $50 \%$ reported being amused; $50 \%$, turned on; $44 \%$ excited; and $40 \%$ happy. Cox (2009) also reported that $90 \%$ of young people sending a sext reported no negative consequences.

Not all experiences were positive, Just under a quarter (21\%) of participants in Mitchell's study reported being very or extremely upset, embarrassed or afraid as a consequence of sending an image. Comparable levels were reported in the Sex and Tech Survey (2008): 22\% were 'grossed out' and 15\% 'turned off'. Unfortunately, no gender breakdowns were provided.

Lee and Croft's (2015) recent review of the literature stresses that while negative scenarios can occur, risk approaches 'do not reflect the experiences expressed by the majority of girls who actually engage in sexting, who are more likely to express motivations associated with pleasure or desire' ( $p$ 454). They strongly argue that the risk discourse within which sexting is most often submerged has significant moral overtones which are themselves rooted in historical attempts to regulate childhood sexuality (Renold, 2005). 
We support this contention and share their concerns about how sexting has been used as an additional site to further problematise and attempt to confine young sexualities.

Nevertheless, we also recognise that new technologies, including sexting, can be used as a means of control and abuse even if, as Lee and Croft contend, this represents a minority experience. Consequently, pleasure, fun, risk and harm all require attention, albeit within a more balanced framework of childhood sexual citizenship and agency (Albury et al., 2010). We need also to remember that childhood, as numerous scholars have shown, is a highly gendered social construction (Corsaro, 2014). Debates about the impact of the sexualisation of children and young women in western societies, especially in respect to the objectification of girls and women, are ongoing (Coy, 2013; Renold et al., 2015). It is therefore important to reflect on how gender is played out in respect to understanding the interaction between pleasure and risk in young people's experiences of sexting.

\subsection{Gender and Sexting}

A variety of studies have indicated that gender is a central factor in understanding the impact of sexting (Ringrose et al., 2013; Lippman and Campbell, 2014). Girls are more likely to experience greater negative impacts due to the gendered double standard of sexual reputations (Renold and Ringrose, 2011; Holland et al., 1998; Renold et al., 2015). This double standard is now applied online where girls are more likely to have derogatory labels (for example 'slut') attributed to them for sending sexual images and to also experience a highly negative impact when messages enter the public domain (Ringrose et al., 2012, Wolak and Finkelhor, 2011). Boys on the other hand, can gain status amongst peers for the same behaviours (Willard, 2010). Wolak and Finkelhor (2011) found that nude or nearly nude images were being used as a form of 'relationship currency' with boys asking for them and placing 'pressures' upon girls to produce/share such images. The young people also reported that sexting brands a girl 'slutty', 'gross' and 'disrespecting themselves'. It is notable that there were no similar derogatory comments about males. One study (Ringrose et al, 2012), based on two inner-city schools, showed that boys were accumulating 'ratings' by possessing and exchanging images of girls' breasts online. The fact that girls suffer more than boys in terms of their reputation is related to wider societal heteronormative expectations about the way girls should act in terms of their sexuality (Egan and Hawkes, 2010; Tolman, 2012).

Responses to sexting tend to reinforce these unequal gender sexual expectations by putting blame on girls for sending images rather than their partners for distributing them (Willard,2010), an emphasis also reflected in some UK and international sexting resources (Ringrose et al 2012). Many have maintained that it is primarily girls and young women's sexual images that are being circulated without their consent, and consequently represents just another facet of male control and power (Hand et al., 2009; Kee, 2005; Powell, 2009; Flood, 2008). 


\subsection{Association between IPVA and sexting}

As we have outlined, there remains some contention regarding the impact of sexting on young people's wellbeing, however, it is generally acknowledged that there is a limited understanding as to the contexts under which young people are exchanging sexual images (Ringrose et al, 2012; Lee and Croft, 2015). One key omission is how young people engage in sexual image exchange within their interpersonal partner relationships and how the wider relationships dynamics mediate these experiences, including interpersonal violence and abuse (IPVA).

IPVA in adult relationships often includes coercive control where men use different tactics to exert power over women, seeking to limit their partner's freedom and agency (Stark, 2007). Forms of coercive control may also be present in the relationships of some young people (Barter et al, 2009; Wood et al, 2011). It remains unclear whether controlling behaviours identified in young relationships (for example constantly checking up on partners; placing restriction on who their partners see or communicate with) constitutes coercive control or rather reflects young people's unresolved struggles around trust and jealously (Barter et al 2009; Fox et al 2013). It is however possible that male partners are using the sexual images sent to them as a means of exerting power over their partners through the threat of sharing, or that sexual images are used by partners as a form of 'relational aggression' (Leadbeater et al, 2008) - to spread rumours to damage a young person's relationship with his/her peers. Girls may also be sending sexual images to fulfil heteronormative expectations that sexual activity is how women should please their partners (Powell, 2009). These expectations are reinforced by the normalisation of these actions within peer groups in what is known as 'cultural violence' - where violence becomes normalised within a particular society (Galtung, 1990; Aghtaie, 2015). We know little, however, about these dynamics at present.

The only previous study to address the association between IPVA and sexting was undertaken by Drouin et al (2015) with 480 US undergraduate University students (average age 20.6 years). This study found that one fifth of participants reported engaging in sexting with a partner when they did not want to. Coercion was generally experienced via pressure (e.g., repeated asking and being made to feel obligated) rather than through more severe forms of coercion (e.g., physical threats). Nevertheless, trauma related to both acts of pressured and forced sexting coercion. Moreover, women reported significantly more trauma at the time of the research (looking back) than at the time the events occurred. The authors premise that this may be due to female participants' anxiety that their sexual image might have been shared which would constitute a further violation. A young man, in contrast, might view the sharing of his sexual images as reflecting his sexual desirability or masculinity. The study also found that sexting coercion was related to both physical sex coercion and IPV, which suggests that sexting coercion may be a form of IPVA violence, 
'providing perpetrators with a new, digital route for physical and sexual victimisation' (Drouin et al., 2015, p197). However, whether findings from research with young adults are replicated in to young people's experiences remains to be established.

\subsection{STIR Study}

The study reported here was funded by the European Commission's Directorate General Justice Daphne III Programme. Building on earlier UK research that found that new technologies could act to extend and intensify interpersonal violence and abuse (IPVA) in young people's relationships (Barter et al., 2009, Wood et al., 2011), the STIR (Safeguarding Teenage Intimate Relationships) study aimed to explore young people's online and face-toface experiences of IPVA in five European countries: Bulgaria, Cyprus, England, Italy and Norway. Study objectives included exploring the incidence and impact of online and offline physical, emotional and sexual forms of violence and abuse in young relationships and these findings are reported in depth elsewhere (Barter et al., 2015). The STIR study allows a focus, for the first time, on young people's experiences of sending/ receiving sexual images within their interpersonal partner relationships and the impact of gender on these processes within a European context.

The five European countries were selected to provide a wide geographical and policy spread and to offer diversity in their levels of gender equality (see EIGE 2013) as well as variations in young people's use of new technologies (Livingstone et al 2011). The countries were chosen to reflect the EU Kids Online survey on children's and young people's differential use of new technologies and associated risks. The sample consisted of European countries identified as having low $(n=2)$; medium $(n=1)$; and high $(n=2)$ levels of internet use and low $(n=2)$; medium $(n=1)$; and high $(n=2)$ internet risks, although risks did not include partner violence. We found that nearly all young people in the sample had access to new technology through mobile platforms.

\section{Method}

The STIR study was conducted in schools across five countries in Europe - Bulgaria, Cyprus, England, Italy, and Norway and involved a paper survey of 4,564 young people aged between 14 and 17. Interviews were also conducted with 100 young people across all the countries. A young people's advisory group was convened in each country to comment on all aspects of the study and these groups assisted with the design and wording of the survey and interview schedule.

\subsection{The survey measures}

The school-based confidential survey explored young people's experience of being both victims and instigators of different forms of interpersonal partner violence and abuse (IPVA): 
face to face violence (including physical and emotional aspects); online abuse, including controlling behaviours and surveillance and sexual violence. The survey also asked young people about their experiences of sexting. The measures employed were based on previous studies of young people's experiences of IPVA (Barter et al., 2009; Radford et al., 2011) and were developed in collaboration with the young people's advisory groups. The measures were included in a single paper survey that was professionally translated into the required languages. Care was taken to ensure that the language was consistent between the countries and the young people's group in each country assisted in ensuring that the layout, length and wording of the survey was young people friendly. The same measures, professionally translated and checked for idioms with the relevant young people's advisory group, were used in all five countries. The actual questions asked in the survey are detailed below:

\subsubsection{Intimate partner violence and abuse questions}

The young people were asked to tick boxes to show the number of times they had experienced the different forms of violence with the options to tick 'never', 'once', 'few times' or 'often'. The questions asked regarding the different forms of violence are as follows:

\section{Face-to-face Emotional violence}

In the survey four questions measured face-to-face emotional IPVA. Respondents were asked 'Have any of your partners ever done any of these things face-to-face': Put you down in a nasty way?; Shouted at you/ screamed in your face/ called you names?; Said negative things about your appearance, body, friends or family?; Threatened to hurt you physically?

\section{Physical violence}

The survey asked 'Have any of your partners ever': Used physical force such as slapping, pushing, hitting or holding you down?; Used more severe physical force such as punching, strangling, beating you up, hitting you with an object?

\section{Online Emotional Violence}

The survey contained 6 questions which measured experiences of online emotional IPVA. Respondents were asked 'Have any of your partners ever done any of these things using a mobile phone, computer or tablet: Put you down or sent you any nasty messages?; Posted nasty messages about you that others could see?; Sent you threatening messages online or by mobile phones?; Used mobile phones or social networking sites to try and control who you can be friends with or where you can go? Constantly checked up on what you have been doing / who you have been seeing, for example, by sending you messages or checking your social networking page all the time?' 
Prior to being asked the above questions, we also asked about use of new technologies. The respondents were asked 'Do you do any of these things from: your mobile phones; your own tablet or personal computer; a shared tablet or computer; never': 'Send or receive texts / emails, instant messages?; Send, upload or receive videos/pictures?; Use social networking sites such as Facebook, Twitter, Ask.fm, Tumlr, Instagram or Flickr or some other site'.

\section{Sexual violence}

Respondents were asked 'Have any of your partners ever: Pressured you into intimate touching or something else?; Physically forced you into intimate touching or something else?; Pressured you into having sexual intercourse?; Physically forced you into having sexual intercourse?'. We gave the following explanation of pressure: 'pressure can include things like a partner saying "I will end the relationship unless you agree to a sexual act" or "If you loved me you would do it".

\subsubsection{Sending and receiving sexual images and text messages questions}

\section{Sending sexual images or text messages:}

Young people were asked: 'Have you ever sent sexual messages or picture of yourself to any of your partners' either during the relationship or after the relationship had ended. They were given options to tick whether this had happened never, once, a few times or often.

We also asked respondents to tick from a list the reasons why they did this. The options given were: to hurt their partner; due to their partner's behaviour; jealousy; to impress others; to get what I wanted; anger; to humiliate them; messing around/joking; everyone does this; other reason.

\section{Impact of sending sexual images}

The survey also asked young people how they felt after they had sent a sexual image and how they felt if the image had been shared by their partner. The following possible responses were provided: feeling upset, unhappy, humiliated, annoyed, scared, angry, bad about themselves, shocked, embarrassed (negative feelings); or if they felt loved, wanted, good about themselves, thought it was funny, (affirmative feelings) or had no effect. The affirmative and negative options were randomised in order to reduce response bias. Respondents could tick as many options as they liked and could tick both affirmative and negative feelings. For the analysis we grouped responses into affirmative only (including no effect), affirmative and negative and negative only. We also grouped together all negative response so that we could explore those who had experienced any detrimental impact.

Sharing of sexual images 
Young people were asked: 'Was the message /picture shared with anyone else?' They could answer with the response options: 'No, it was just between me and my partner; Yes, my partner/ex-partner showed it to others on their phone; Yes, my partner/ex-partner shared it online; Yes, I sent it to others online/by phone; I don't know / I am not sure.

\section{Receiving sexual images or text messages}

Respondents were asked: 'Have any of your partner/s ever sent you any sexual messages or pictures of themselves?' either during the relationship or after the relationship had ended giving them the option to tick never, once, a few times, or often.

We asked the young people 'Did they send it because you asked them to? (Yes, No, Sometimes)' and 'Did you share the message with anyone else?', giving them the options to tick: 'No, it was just between me and my partner; Yes, I showed my friends the message on my mobile phone; Yes, I shared the message online'. We asked them 'If the message was shared - why did you do this?'. They could respond: 'Don't know; As a joke; Because I was annoyed with my partner; Because our relationship had ended and I felt upset; Because my friends pressured me to show it to them; Because I asked my partner and they said they didn't mind'.

\subsubsection{Other questions}

Demographic information was also collected in the survey (gender, age, ethnicity, disability, who they live with) along with other background information (how they were getting on at school, experiences of bullying, friends use of aggressive behaviour, experiences of family violence, and viewing pornography, age of their partner) and some questions around who the young people told or how they reacted to their experiences. Questions on the impact of IPVA on the young people were also asked with similar options outlined to those described above for the impact of sending / sharing sext messages. Results from these different elements of the survey can be found in the five brieifing papers developed from the study (see http://stiritup.eu/app-and-resources/). In addition, the main findings on incidence rates are reported by Barter et al. (2015).

\subsection{Non survey data}

The focus of this article is on the occurrence, impact, motivations and context for sexting in young people's interpersonal partner relationships. Whilst both quantitative and qualitative data were collected, space considerations do not allow for exploration of both aspects within this article. This article focuses on the quantitative findings while qualitative findings are reported by Barter et al. (2015).

\subsection{Ethical approval and consent}

Ethical approval for the study was granted by the School for Policy Studies ethics committee at the University of Bristol. Surveys were confidential and anonymous. All young people 
provided informed consent. Parents/carers were requested to provide opt-in or opt-out consent depending on the country requirements. We used a broad definition of relationships - referring to both short and longer term encounters.

\section{Analysis}

Descriptive statistics were run for each country. Pearson's Chi square test was used to determine statistical significance, reporting differences where $p<.05$.

\subsection{Sample}

The survey was not a random stratified sample and therefore we cannot extrapolate findings to give national rates within countries, we can only give findings for each country sample. The findings however, do indicate some potential differences in relation to the countries which took part. We aimed to achieve a mixed sample of schools serving more and less affluent populations and to exclude single sex schools. Recruitment was not straightforward, and although in most countries recruitment was consistent with the framework established, a single sex boys' school was included in one country. We were however unable to achieve a random sample due to the difficulties in obtaining agreement from schools to participate. For example in Norway over 100 schools were approached but only 10 agreed. In Italy and Bulgaria similar issues were faced. The survey was undertaken in 45 schools with young people aged between 14 and 17 years-old. Each country surveyed approximately 1000 young people except Cyprus where, due to the smaller population size, just over 600 respondents were included.

Overall, 4,564 young people aged 14-17 completed the survey across the five countries. The mean age of respondents was similar across countries, ranging from 14.73 in England to 15.29 in Italy. Of these $72 \%$ had been in a relationship. Most of the young people (96\%) had had a partner of the opposite sex. Table 1 gives the breakdown by age and gender for the 3,299 young people who had been in a relationship, for each country. All subsequent analysis is undertaken on those who reported some form of an interpersonal partner relationship.

Table 1: Sample of young people who had a relationship by gender and age for the 5 countries

\begin{tabular}{llllll}
\hline & Bulgaria & Cyprus & England & Italy & Norway \\
\hline Female & $48 \%(313)$ & $54 \%(272)$ & $55 \%(401)$ & $34 \%(293)$ & $50 \%(272)$ \\
\hline Male & $52 \%(335)$ & $46 \%(233)$ & $46 \%(323)$ & $66 \%(565)$ & $50 \%(270)$ \\
\hline Total & $100 \%(648)$ & $100 \%(505)$ & $100 \%(724)$ & $100 \%(858)$ & $100 \%(542)$
\end{tabular}




\begin{tabular}{llllll}
\hline Missing & 9 & 4 & 2 & 7 \\
\hline 14 & $29 \%(186)$ & $18 \%(92)$ & $31 \%(228)$ & $20 \%(168)$ & $27 \%(145)$ \\
\hline 15 & $19 \%(124)$ & $22 \%(109)$ & $56 \%(433)$ & $37 \%(312)$ & $35 \%(189)$ \\
\hline 16 & $37 \%(240)$ & $29 \%(147)$ & $9 \%(67)$ & $34 \%(293)$ & $33 \%(183)$ \\
\hline 17 & $16 \%(101)$ & $31 \%(157)$ & 0 & $9 \%(80)$ & $6 \%(31)$ \\
\hline Total & $100 \%(651)$ & $100 \%(505)$ & $100 \%(728)$ & $100 \%(853)$ & $100 \%(548)$ \\
\hline Missing & 6 & & & 7 & 1 \\
\hline
\end{tabular}

\subsection{Use of new technologies}

In all countries the use of new technologies was high (93 per cent to 100 per cent across countries) and nearly all the young people reported having access to a mobile phone or computer on which they could send and receive images as well as text messages (79 per cent to 93 per cent across countries).

\section{Results}

This section reports the findings from the survey on the young people's experience of sexting. It explores, within the samples in each country, rates for: sending, receiving, and sharing sexual images; the impact of sending sexual images; reasons for sending sexual images, and associations between sending images and experiences of the different types of interpersonal violence. All of these elements are explored by gender. The rates for sending / receiving sexual images are also explored by age.

\subsection{Sending and /or receiving sexual images}

We asked the young people in the survey if they had ever sent a sexual message or picture of themselves to any of their partners during their relationship or after it had ended.

Although we believe the primary source of exchange to be sexual images, we asked about both sexual images and messages because initially we were unsure if all countries would have access to devices on which they could send images. As reported later, nearly all young people had access to such devices and it is our assumption that the majority of young people were engaged in the exchange of sext messages. Klettke's review (2014) reported a similar average rate for studies which included images only in their definition as to those which included images and messages. 
Table 2 shows that across all countries the highest proportion of young people sending sext messages to a partner either during or after the relationship had ended was in England (38\%), followed by Norway (30\%), and Bulgaria (28\%). In Italy, $22 \%$ of young people had sent a sext. Only 10 per cent of the young people in Cyprus reported sending a sext message. There were gender differences in all countries other than Bulgaria, however, the direction of this difference varied by country. For example, in England and Norway, girls were more likely than boys to say they had sent a sexual image, whereas in Cyprus and Italy the opposite occurred.

Table 2: Sending sexual images by gender

\begin{tabular}{lllll}
\hline & Female & Male & Total & Chi square \\
\hline Bulgaria & $80(26 \%)$ & $94(29 \%)$ & $174(28 \%)$ & Not significant \\
\hline Cyprus & $15(6 \%)$ & $34(15 \%)$ & $49(10 \%)$ & $X^{2}(1)=12.030, p<.001$ \\
& & & & \\
\hline England & $174(44 \%)$ & $101(32 \%)$ & $275(38 \%)$ & $X^{2}(1)=11.092, p<.001$ \\
\hline Italy & $47(16 \%)$ & $139(25 \%)$ & $186(22 \%)$ & $X^{2}(1)=8.431, p<.05$ \\
\hline Norway & $91(34 \%)$ & $66(25 \%)$ & $157(30 \%)$ & $X^{2}(1)=4.394, p<.05$ \\
& & & & \\
\hline
\end{tabular}

The likelihood of having sent a sexual image increased with age in all the countries for both boys and girls, although differences were not significant for Cyprus (see Table 3). Whilst proportions were lower for the younger age groups, it is still of interest to note that in some countries as many as a quarter of 14 year olds had sent a sexual image (Bulgaria and England). Being an older young person was also found to be positively predictive of a higher incidence of sending / receiving sexual images in other studies (Cox communications, 2009; Mitchell et al, 2012; Rice et al, 2012).

Table 3: Sending sexual images by age

\begin{tabular}{lllllll}
\hline & Age 14 & Age 15 & Age 16 & Age 17 & Total & Chi square \\
\hline Bulgaria & $35(19 \%)$ & $28(24 \%)$ & $74(32 \%)$ & $37(37 \%)$ & $174(28 \%)$ & $X^{2}(3)=13.621, p<.05$ \\
\hline Cyprus & $5(6 \%)$ & $9(8 \%)$ & $14(10 \%)$ & $21(14 \%)$ & $49(10 \%)$ & Not significant \\
\hline England & $60(26 \%)$ & $186(43 \%)$ & $31(48 \%)$ & n/a & $277(38 \%)$ & $X^{2}(2)=20.412, p<.001$
\end{tabular}




\begin{tabular}{lcccccc}
\hline Italy & $28(17 \%)$ & $61(20 \%)$ & $71(24 \%)$ & $26(33 \%)$ & $186(22 \%)$ & $X^{2}(3),=9.903, p<.05$ \\
\hline Norway & $21(15 \%)$ & $51(28 \%)$ & $72(40 \%)$ & $14(45 \%)$ & $188(29 \%)$ & $X^{2}(3)=28.245, p<.001$
\end{tabular}

Table 4 shows that young people in England had the highest likelihood of receiving a sexual image from a partner either during the relationship or after the relationship had ended, with almost half of those who reported an interpersonal relationship stating this had occurred (48\%). Just over a third of young people in Bulgaria (35\%) and Norway (36\%) said that they had received a sexual image from a partner, and just under a third in Italy (30\%). Cyprus again had the lowest proportion of young people who had received a sexual image (14\%).

Table 4: Receiving sexual images by gender

\begin{tabular}{lllll}
\hline & Female & Male & Total & Chi square \\
\hline Bulgaria & $105(35 \%)$ & $114(36 \%)$ & $219(35 \%)$ & Not significant \\
\hline Cyprus & $23(9 \%)$ & $43(20 \%)$ & $66(14 \%)$ & $\mathrm{X}^{2}(1)=12.403, \mathrm{p}<.001$ \\
\hline England & $192(49 \%)$ & $148(47 \%)$ & $340(48 \%)$ & Not significant \\
\hline Italy & $53(18 \%)$ & $199(36 \%)$ & $252(30 \%)$ & $\mathrm{X}^{2}(1)=27.621, \mathrm{p}<.001$ \\
\hline Norway & $99(37 \%)$ & $90(35 \%)$ & $189(36 \%)$ & Not significant \\
\hline
\end{tabular}

In relation to gender, table 4 (above) shows that in Cyprus and Italy, boys were around twice as likely to say that they had received a sexual image from their partner as girls. Whereas in England and Bulgaria and Norway, proportions were similar for girls and boys. Thus, more boys than girls in Cyprus and Italy stated they had received sexual images whereas, fewer girls reported sending such images. This may indicate that girls are reluctant to admit to sending sexual images in Cyprus and Italy. The association between sending sexual images and subjective impact is examined later in this article and provides some evidence to support this contextion.

Table 5 gives the rates for young people receiving sexual images by age. A general pattern can be observed that, as participants increased in age, so did the reporting of receiving sexual images. However, it is still important to recognise that younger adolescents were also receiving sexual images ( $9 \%$ to $33 \%$ across countries).

Table 5: Receiving sexual images by age 


\begin{tabular}{lllllll}
\hline & Age 14 & Age 15 & Age 16 & Age 17 & Total & Chi square \\
\hline Bulgaria & $49(28 \%)$ & $43(37 \%)$ & $87(38 \%)$ & $39(41 \%)$ & $218(35 \%)$ & Not significant \\
\hline Cyprus & $8(9 \%)$ & $9(9 \%)$ & $22(16 \%)$ & $27(18 \%)$ & $66(14 \%)$ & Not significant \\
\hline England & $73(33 \%)$ & $231(54 \%)$ & $38(59 \%)$ & $n / a$ & $342(48 \%)$ & $X^{2}(2)=29.792, p<.001$ \\
\hline Italy & $43(26 \%)$ & $81(26 \%)$ & $96(33 \%)$ & $31(40 \%)$ & $251(30 \%)$ & $X^{2}(3)=8.355, p<.05$ \\
\hline Norway & $30(22 \%)$ & $68(37 \%)$ & $78(43 \%)$ & $14(50 \%)$ & $190(36 \%)$ & $X^{2}(3)=18.543, p<.001$
\end{tabular}

\subsubsection{Reason for receiving sexual images}

We asked the participants who had received sexual images if they had asked their partner to send them the image. A gendered pattern emerges: boys were more likely than girls to have asked their partner to send the image, although differences were only significant in England (18 per cent for boys compared to 3 per cent for girls $\left(X^{2}(1)=34.490, p<.001\right)$.

\subsubsection{Reciprocal sending / receiving of sexual images}

In all countries, sending/receiving sexual images was commonly reciprocal, with around two- thirds of those having sent an image also reporting having received an image. In Norway and England some gender difference was found - with around 80 per cent of girls who had sent sexual images also having received sexual images, compared to around 60 per cent of boys. This is likely to reflect the higher proportion of girls than boys in these countries who reported having sent a sexual image.

\subsubsection{Sharing Images}

Table 6 shows that there were substantive country differences in the number of young people who reported awareness that the sexual images that they sent had been shared by their partner. In England, around a third (32\%) of those who had sent a sexual image to their partner reported that it was shared, compared to around a fifth (21\%) of young people in Norway, 11 per cent in Bulgaria and 8 per cent in Italy (numbers were too low in Cyprus to report percentages). In England and Norway, girls compared to boys were significantly more likely to report that the image was shared by a partner (England $-42 \%$ for girls compared to 13 per cent of boys, and Norway - 27 per cent for girls compared to 12 per cent for boys). In all five countries, boys were more likely to say that they shared the image they had received than girls, although these differences were only statistically significant in Bulgaria (see Table 6). In some countries it may be possible that boys under-reported their level of sharing an image they had received. For example, in England and Norway, girls were much more likely to report that an image was shared by a partner than boys were to report that they shared an image.

Table 6: Sharing sexual images 


\begin{tabular}{lllll}
\hline $\begin{array}{l}\text { Partner shared an } \\
\text { image you sent }\end{array}$ & Female & Male & Total & Chi square \\
\hline Bulgaria & $7(9 \%)$ & $9(12 \%)$ & $16(11 \%)$ & Not significant \\
\hline Cyprus & $\mathrm{n}<5$ & $\mathrm{n}<5$ & $\mathrm{n}<5$ & $\begin{array}{l}\text { Expected cell counts } \\
\text { too low }\end{array}$ \\
\hline England & $67(42 \%)$ & $12(13 \%)$ & $79(32 \%)$ & $\mathrm{X}^{2}(1)=22.135, \mathrm{p}<.001$ \\
\hline Italy & $\mathrm{n}<5$ & $12(9 \%)$ & $13(8 \%)$ & $\begin{array}{l}\text { Expected cell counts } \\
\text { too low }\end{array}$ \\
\hline Norway & $23(27 \%)$ & $7(12 \%)$ & $30(21 \%)$ & $\mathrm{X}^{2}(1)=4.827, \mathrm{p}<.05$ \\
\hline $\begin{array}{l}\text { You shared an } \\
\text { image you received } \\
\text { from a partner }\end{array}$ & $\mathrm{Female}$ & $\mathrm{Male}$ & $\mathrm{T}$ & \\
\hline Bulgaria & $18(18 \%)$ & $33(30 \%)$ & $51(24 \%)$ & $\mathrm{X}^{2}(1)=4.107, \mathrm{p}<.05$ \\
\hline Cyprus & $\mathrm{n}<5$ & $11(28 \%)$ & $14(23 \%)$ & Not significant \\
\hline England & $24(13 \%)$ & $22(15 \%)$ & $46(14 \%)$ & Not significant \\
\hline Italy & $6(12 \%)$ & $35(18 \%)$ & $41(17 \%)$ & Not significant \\
\hline Norway & $11(11 \%)$ & $14(16 \%)$ & $25(13 \%)$ & Not significant \\
\hline
\end{tabular}

\subsubsection{Impact of sending Sexual images}

Table 7 shows that, across all countries, over half the young people who sent a sexual image reported affirmative only feelings (see methods section for a description of measures). In Bulgaria and Cyprus, this was especially high with around $80 \%$ of both boys and girls recording affirmative only responses for sending sexual images (although in Cyprus it should be noted that this amounted to only 10 female participants). In contrast, for England, Italy and Norway, statistically significant gender differences were found in relation to the impact of sending a sexual image; girls were less likely to give affirmative only responses than boys in these countries (see table 7). For example, in England, $91 \%$ of the boys reported affirmative only feelings compared to $41 \%$ of the girls. Consequently - in England, Italy and Norway, girls were much more likely to report negative feelings after sending a sexual image than boys.

Table 7: How felt after sending a sexual image by gender

$\begin{array}{llll}\text { Affirmative } & \text { Mixed } & \text { Negative } & \text { Chi square } \\ \text { only } & \text { affirmative } & \text { only negative Chi square } \\ \text { and } & & \begin{array}{l}\text { (grouping } \\ \text { mixed and }\end{array} \\ \text { negative } & & \text { negative } \\ & & \text { only) }\end{array}$




\section{Bulgaria}

\begin{tabular}{|c|c|c|c|c|c|c|}
\hline Female & 68 (87\%) & 7 (9\%) & $n<5$ & \multirow{3}{*}{$\begin{array}{l}\text { Not } \\
\text { significant }\end{array}$} & 10 (13\%) & \multirow{3}{*}{$\begin{array}{l}\text { Not } \\
\text { significant }\end{array}$} \\
\hline Male & $64(80 \%)$ & 9 (11\%) & 7 (9\%) & & $16(20 \%)$ & \\
\hline Total & 132 (84\%) & 16 (10\%) & $10(6 \%)$ & & 26 (17\%) & \\
\hline
\end{tabular}

\section{Cyprus}

\begin{tabular}{|c|c|c|c|c|c|c|}
\hline Female & $10(77 \%)$ & $n<5$ & $n<5$ & \multirow{3}{*}{$\begin{array}{l}\text { Expected } \\
\text { cell counts } \\
\text { too low }\end{array}$} & $n<5$ & \multirow{3}{*}{$\begin{array}{l}\text { Expected } \\
\text { cell counts } \\
\text { too low }\end{array}$} \\
\hline Male & $23(82 \%)$ & $n<5$ & $n<5$ & & $5(18 \%)$ & \\
\hline Total & 33 (81\%) & $n<5$ & $n<5$ & & $8(20 \%)$ & \\
\hline
\end{tabular}

\section{England}

\begin{tabular}{|c|c|c|c|c|c|c|}
\hline Female & 69 (41\%) & $50(29 \%)$ & $51(30 \%)$ & \multirow{3}{*}{$\begin{array}{l}X^{2} \\
(2)=61.411 \\
D<.001\end{array}$} & 101 (59\%) & \multirow{3}{*}{$\begin{array}{l}x^{2}(1)=60.1 \\
78, p<.001\end{array}$} \\
\hline Male & 80 (91\%) & $n<5$ & $7(8 \%)$ & & $8(9 \%)$ & \\
\hline Total & 149 (58\%) & $51(20 \%)$ & $58(23 \%)$ & & $109(42 \%)$ & \\
\hline
\end{tabular}

\section{Italy}

\begin{tabular}{|c|c|c|c|c|c|c|}
\hline Female & 25 (57\%) & $7(16 \%)$ & $12(27 \%)$ & \multirow{3}{*}{$\begin{array}{l}x^{2} \\
(2)=9,895, \\
p<.05\end{array}$} & $19(43 \%)$ & \multirow{3}{*}{$\begin{array}{l}X^{2} \\
(1)=5.157, \\
p<.05\end{array}$} \\
\hline Male & $101(75 \%)$ & $22(16 \%)$ & $12(9 \%)$ & & $34(25 \%)$ & \\
\hline Total & $126(70 \%)$ & $29(16 \%)$ & $24(13 \%)$ & & 53 (29\%) & \\
\hline
\end{tabular}

\section{Norway}

\begin{tabular}{|c|c|c|c|c|c|c|}
\hline Female & $51(57 \%)$ & $16(18 \%)$ & $23(26 \%)$ & & $39(43 \%)$ & \\
\hline Male & $52(85 \%)$ & $n<5$ & $6(10 \%)$ & $x^{2}$ & $9(15 \%)$ & $x^{2}(1)=$ \\
\hline Total & $103(68 \%)$ & $19(13 \%)$ & $29(19 \%)$ & $\begin{array}{l}(2)=13.810 \\
, p<.001\end{array}$ & 48 (32\%) & 13.695, \\
\hline
\end{tabular}

$p<.001$

These findings highlight the mixture of feelings associated with sending / receiving of sexual images. Even in countries where more girls reported negative feelings after sending sexual images, there was still a large proportion that reported exclusively affirmative only feelings ( $41 \%$ of girls who had sent a sexual image in England and $57 \%$ in Norway and Italy). 


\subsubsection{Sharing and Impact}

We also explored if an association existed between having an image shared and the reported impact of sending an image for girls in England, Norway and Italy where negative impact was particularly high. Table 8 shows that $61 \%$ of girls in England and $47 \%$ in Norway who reported a negative impact after sending a sexual image said that the image was shared. In comparison only $21 \%$ of girls in England and $15 \%$ in Norway who reported an affirmative only impact said that the image was shared. However, this does not explain the high negative impact in Italy where although 43 per cent of girls reported negative feelings after sending sexual images, fewer than five girls reported that an image they sent to a partner was shared.

In Italy, it is possible that the high negative impact for the girls who reported sending sexual images reflects the heightened gender norms within Italy, and that girls feel negative after sending images because of concerns over their reputations, whether these images are shared or not. This may support the findings reported earlier of the possible non-reporting of sexual image sending by girls in comparison to the higher rates reported by boys of receiving sexual images from female partners. Young people may be sending / receiving sexual images in more covert ways in some countries despite lower statistical reporting, but further research is needed to explore the internal factors within countries which may influence reporting behaviours.

Very few boys reported a negative impact after sending a sexual image so it was not possible to report any association between impact and the sharing of sexual images for boys.

Table 8: Proportion who reported affirmative or negative impact after sending images by whether the image was shared (Girls only)

\begin{tabular}{lllll}
\hline \multirow{2}{*}{ England } & Female & $\begin{array}{l}\text { Affirmative } \\
\text { only impact }\end{array}$ & $\begin{array}{l}\text { Any } \\
\text { negative } \\
\text { impact }\end{array}$ & Chi square \\
\cline { 2 - 4 } & Shared & $14(21 \%)$ & $54(61 \%)$ & $X^{2}(1)=29.376, p<.001$ \\
\cline { 2 - 4 } Norway & Not shared & $53(79 \%)$ & $34(39 \%)$ & \\
\cline { 2 - 4 } & Shared & $7(15 \%)$ & $17(47 \%)$ & $X^{2}(1)=8.887, p=<.05$ \\
\cline { 2 - 4 } & Not shared & $40(85 \%)$ & $19(53 \%)$ & \\
\hline
\end{tabular}

We asked the young people how they felt about the image being shared. We can only explore results for girls in England and Norway as very few reported sharing in other countries and only a minority of boys reported their image had been shared. In England and 
Norway, nearly all girls who reported that an image was shared said that this had a negative only impact on them (97 per cent in England and 83 per cent in Norway).

\subsubsection{Motivations for sending / receiving sexual images and impact}

We asked participants about their motivations for sending sexual images. The possible survey responses can be seen in table 9 . The most common reasons for boys and girls in all countries were: because their partner asked them to; to feel sexy/ be flirtatious; in response to an image their partner sent and as a joke. Girls in England and Norway were around twice as likely as boys to say that their reason for sending a sexual image was because their partner asked them to. There was no difference between boys and girls in other countries in relation to this.

In England, there was some evidence of girls sending images for more negative reasons. Around a quarter (27 per cent) of the girls in England who had sent a sexual image did so because their partner pressured them to, and 43 per cent said they sent a sexual image or text to prove their commitment to a partner. We also explored associations between the more negative reasons for sending sexual images and female participants reported subjective impacts. In England, nearly all the girls (98\%) who had sent an image because they felt pressured reported a negative impact compared to 45 per cent of those who did not report pressure $\left(X^{2}(1)=39.832, p<.001\right)$. Similarly, 74 per cent of those who sent an image to prove their commitment reported a negative impact compared to 47 per cent who did not report this reason $\left(X^{2}(1)=12.511, p<.001\right)$. We also asked if peers had pressured them to send an image to a partner however, very few young people reported this so we have not included this in the analysis.

We also found that in Bulgaria, England and Norway girls were significantly more likely than boys to say they had sent a sexual image to get their partner's attention. We therefore need to know more about girl's motivations in this respect. It may be that girls are sending sexual images because they do not feel they receive sufficient attention or consideration in their relationships and need to use their body to heighten their partner's interest and attention.

Table 9: Motivations for sending sexual images by gender

\begin{tabular}{lclll}
\hline As a joke / to be funny & Female & Male & Total & Chi square \\
\hline Bulgaria & $30(37 \%)$ & $34(39 \%)$ & $64(38 \%)$ & Not significant \\
\hline Cyprus & $7(47 \%)$ & $8(27 \%)$ & $15(33 \%)$ & Not significant \\
\hline England & $36(21 \%)$ & $36(36 \%)$ & $72(26 \%)$ & $X^{2}(1)=7.992, p<.05$ \\
\hline Italy & $11(24 \%)$ & $35(25 \%)$ & $46(25 \%)$ & Not significant \\
\hline
\end{tabular}




\begin{tabular}{|c|c|c|c|c|}
\hline Norway & $13(14 \%)$ & $11(17 \%)$ & $24(15 \%)$ & Not significant \\
\hline $\begin{array}{l}\text { To feel sexy / be } \\
\text { flirtatious }\end{array}$ & Female & Male & Total & Chi square \\
\hline Bulgaria & 41 (51\%) & $18(21 \%)$ & $59(25 \%)$ & $X^{2}(1)=16.488, p<.001$ \\
\hline Cyprus & 7 (47\%) & $12(40 \%)$ & $19(42 \%)$ & Not significant \\
\hline England & $84(48 \%)$ & $57(57 \%)$ & $141(51 \%)$ & Not significant \\
\hline Italy & $16(36 \%)$ & $35(25 \%)$ & $5(28 \%)$ & Not significant \\
\hline Norway & $38(42 \%)$ & $22(33 \%)$ & $60(38 \%)$ & Not significant \\
\hline My partner asked me to & Female & Male & Total & Chi square \\
\hline Bulgaria & $26(32 \%)$ & $24(28 \%)$ & $50(30 \%)$ & Not significant \\
\hline Cyprus & $5(33 \%)$ & $11(37 \%)$ & $16(36 \%)$ & Not significant \\
\hline England & $98(56 \%)$ & $29(29 \%)$ & $127(46 \%)$ & $X^{2}(1)=18.275, p<.001$ \\
\hline Italy & $20(44 \%)$ & $61(44 \%)$ & $81(44 \%)$ & Not significant \\
\hline Norway & $42(47 \%)$ & $13(20 \%)$ & $55(35 \%)$ & $X^{2}(1)=11.765, p<.001$ \\
\hline $\begin{array}{l}\text { My partner pressured } \\
\text { me to }\end{array}$ & Female & Male & Total & Chi square \\
\hline Bulgaria & $5(6 \%)$ & $8(9 \%)$ & $13(8 \%)$ & Not significant \\
\hline Cyprus & $\mathrm{n}<5$ & $\mathrm{n}<5$ & $\mathrm{n}<5$ & $\begin{array}{l}\text { Expected cell counts } \\
\text { too low }\end{array}$ \\
\hline England & $47(27 \%)$ & $7(7 \%)$ & $54(20 \%)$ & $X^{2}(1)=15.901, p<.001$ \\
\hline Italy & $\mathrm{n}<5$ & $5(4 \%)$ & $6(3 \%)$ & $\begin{array}{l}\text { Expected cell counts } \\
\text { too low }\end{array}$ \\
\hline Norway & $15(17 \%)$ & $\mathrm{n}<5$ & $18(12 \%)$ & $X^{2}(1)=5.371, p<.05$ \\
\hline $\begin{array}{l}\text { To prove my feelings / } \\
\text { commitment }\end{array}$ & Female & Male & Total & Chi square \\
\hline Bulgaria & $8(10 \%)$ & $10(12 \%)$ & $18(11 \%)$ & Not significant \\
\hline Cyprus & $7(47 \%)$ & $9(30 \%)$ & $16(36 \%)$ & Not significant \\
\hline England & $75(43 \%)$ & $13(13 \%)$ & $88(32 \%)$ & $X^{2}(1)=25.749, p<.001$ \\
\hline Italy & $5(11 \%)$ & $25(18 \%)$ & $30(16 \%)$ & Not significant \\
\hline Norway & $13(14 \%)$ & $13(20 \%)$ & $26(17 \%)$ & Not significant \\
\hline To get attention & Female & Male & Total & Chi square \\
\hline Bulgaria & $23(28 \%)$ & $13(15 \%)$ & $36(21 \%)$ & $X^{2}(1)=4.509, p<.05$ \\
\hline Cyprus & $\mathrm{n}<5$ & $\mathrm{n}<5$ & $\mathrm{n}<5$ & $\begin{array}{l}\text { Expected cell counts } \\
\text { too low }\end{array}$ \\
\hline England & $22(13 \%)$ & $\mathrm{n}<5$ & $25(9 \%)$ & $X^{2}(1)=6.986, p<.05$ \\
\hline Italy & $\mathrm{n}<5$ & $\mathrm{n}<5$ & $7(4 \%)$ & $\begin{array}{l}\text { Expected cell counts } \\
\text { too low }\end{array}$ \\
\hline
\end{tabular}




\begin{tabular}{lllll}
\hline Norway & $20(22 \%)$ & $\mathrm{n}<5$ & $21(13 \%)$ & $\left.\mathrm{X}^{2} 1\right)=13.825, \mathrm{p}<.001$ \\
\hline To show off & Female & Male & Total & Chi square \\
\hline Bulgaria & $6(7 \%)$ & $7(8 \%)$ & $13(8 \%)$ & Not significant \\
\hline Cyprus & $\mathrm{n}<5$ & $5(17 \%)$ & $5(11 \%)$ & $\begin{array}{l}\text { Expected cell counts } \\
\text { too low }\end{array}$ \\
\hline England & $12(7 \%)$ & $15(15 \%)$ & $27(10 \%)$ & $\mathrm{X}^{2}(1)=4.837, \mathrm{p}<.05$ \\
\hline Italy & $\mathrm{n}<5$ & $12(9 \%)$ & $14(8 \%)$ & $\begin{array}{l}\text { Expected cell counts } \\
\text { too low }\end{array}$ \\
\hline Norway & $16(18 \%)$ & $9(14 \%)$ & $25(16 \%)$ & Not significant \\
\hline $\begin{array}{l}\text { In response to a similar } \\
\text { image my partner had }\end{array}$ & Female & Male & Total & Chi square \\
sent me & & & & \\
\hline Bulgaria & & & & \\
\hline Cyprus & $23(28 \%)$ & $20(23 \%)$ & $43(26 \%)$ & Not significant \\
\hline England & $\mathrm{n}<5$ & $11(37 \%)$ & $15(33 \%)$ & Not significant \\
\hline Italy & $52(30 \%)$ & $45(45 \%)$ & $97(35 \%)$ & X'(1)=6.682, $\mathrm{p}<.05$ \\
\hline Norway & $19(42 \%)$ & $59(42 \%)$ & $78(42 \%)$ & Not significant \\
\hline
\end{tabular}

\subsection{Interpersonal Partner Violence and Abuse (IPVA) and sending sexual images}

One of the aims of the STIR survey was to explore the incidence and impact of offline and online forms of interpersonal partner violence. We asked participants about their experiences of face to face violence (including physical and emotional aspects); online abuse (including controlling behaviours and surveillance) and pressured and forced sexual coercion. Detailed findings on the incidence and impact of IPVA are reported elsewhere (forthcoming).

Asking young people about their IPVA experiences and their experiences of sending and receiving sexual images allowed us to examine the association between these two factors. We explored the different forms of IPVA separately to understand if there were any different associations between having experienced online or offline forms of IPVA and the sending/receiving of sexual images. This section will explore these associations.

\subsubsection{Face to face violence and sending / receiving of sexual images}

Table 10 shows that across all five countries, a significant association was found between sending sexual images and being a victim of face-to-face IPVA for both boys and girls. This was the case for both emotional and physical forms of face-to-face IPVA. In all countries, boys and girls were around twice as likely to have sent their partner a sexual image or text if 
they were a victim of emotional partner violence compared to those who were not a victim of emotional partner violence. For example, in Norway, $59 \%$ of those who reported being a victim of face-to-face IPVA had sent a sext message compared to $21 \%$ of those who had not been a victim of emotional IPVA. This difference was accentuated more for those who were victims of physical partner violence. For brevity, the tables only give rates for sending images. However, a significant association was also found for receiving sexual images and experiencing face-to-face violence (emotional and physical) which is not surprising due to the high correlation between sending and receiving images (although in Italy this difference was not significant in relation to girls and physical violence).

Table 10: Proportion who were victims of emotional IPVA who had sent a sexual image

\begin{tabular}{|c|c|c|c|c|c|c|}
\hline & Female & & & Male & & \\
\hline & $\begin{array}{l}\text { Victim of } \\
\text { emotional } \\
\text { violence }\end{array}$ & $\begin{array}{l}\text { Not victim } \\
\text { of } \\
\text { emotional } \\
\text { violence }\end{array}$ & Chi square & $\begin{array}{l}\text { Victim of } \\
\text { emotional } \\
\text { violence }\end{array}$ & $\begin{array}{l}\text { Not victim } \\
\text { of } \\
\text { emotional } \\
\text { violence }\end{array}$ & Chi square \\
\hline Bulgaria & $43(34 \%)$ & $37(20 \%)$ & $\begin{array}{l}X^{2}(1)=7.614 \\
p<.05\end{array}$ & 56 (51\%) & $38(18 \%)$ & $\begin{array}{l}X^{2}(1)=39.23 \\
0, p<.001\end{array}$ \\
\hline Cyprus & $9(11 \%)$ & $6(3 \%)$ & $\begin{array}{l}X^{2}(1)=6.705 \\
p<.05\end{array}$ & $19(26 \%)$ & $14(9 \%)$ & $\begin{array}{l}x^{2}(1)=11.28 \\
9, p<.001\end{array}$ \\
\hline England & $113(59 \%)$ & $61(30 \%)$ & $\begin{array}{l}X^{2}(1)=34.09 \\
7, p<.001\end{array}$ & $46(53 \%)$ & $55(24 \%)$ & $\begin{array}{l}X^{2}(1)=25.92, \\
p<.001\end{array}$ \\
\hline Italy & 32 (27\%) & $15(9 \%)$ & $\begin{array}{l}X^{2}(1)=16.67 \\
4, p<.001\end{array}$ & $80(35 \%)$ & $58(18 \%)$ & $\begin{array}{l}x^{2}(1)=21.42 \\
3, p<.001\end{array}$ \\
\hline Norway & $51(59 \%)$ & $39(21 \%)$ & $\begin{array}{l}X^{2}(1)=37.92 \\
8, p<.001\end{array}$ & $25(53 \%)$ & 41 (19\%) & $\begin{array}{l}X^{2}(1)==23.4 \\
21, p<.001\end{array}$ \\
\hline
\end{tabular}

Table 11: Proportion who were victims of physical IPVA who had sent a sexual image

\begin{tabular}{|c|c|c|c|c|c|}
\hline Female & & & Male & & \\
\hline $\begin{array}{l}\text { Victim of } \\
\text { physical } \\
\text { violence }\end{array}$ & $\begin{array}{l}\text { Not victim } \\
\text { of } \\
\text { physical } \\
\text { violence }\end{array}$ & Chi square & $\begin{array}{l}\text { Victim of } \\
\text { physical } \\
\text { violence }\end{array}$ & $\begin{array}{l}\text { Not } \\
\text { victim of } \\
\text { physical } \\
\text { violence }\end{array}$ & Chi square \\
\hline
\end{tabular}




\begin{tabular}{|c|c|c|c|c|c|c|}
\hline Bulgaria & $19(54 \%)$ & $61(22 \%)$ & $\begin{array}{l}X^{2}(1)=16.335 \\
p<.001\end{array}$ & $26(58 \%)$ & $68(25 \%)$ & $\begin{array}{l}X^{2}(1)=39.230 \\
p<.001\end{array}$ \\
\hline Cyprus & $6(21 \%)$ & $9(4 \%)$ & $\begin{array}{l}X^{2}(1)=14.662, \\
p<.001\end{array}$ & $8(38 \%)$ & $26(13 \%)$ & $\begin{array}{l}X^{2}(1)=11.289 \\
p=.001\end{array}$ \\
\hline England & 67 (75\%) & 107 (35\%) & $\begin{array}{l}X^{2}(1)=46.662, \\
p<.001\end{array}$ & $19(49 \%)$ & $82(29 \%)$ & $\begin{array}{l}X^{2}(1)=25.925, \\
p<.001\end{array}$ \\
\hline Italy & $8(31 \%)$ & 39 (15\%) & $\begin{array}{l}X^{2}(1)=4.550 \\
p<.05\end{array}$ & $33(45 \%)$ & $\begin{array}{l}104 \\
(21 \%)\end{array}$ & $\begin{array}{l}X^{2}(1)=21.423, \\
p<.001\end{array}$ \\
\hline Norway & 34 (71\%) & $56(25 \%)$ & $\begin{array}{l}X^{2}(1)=36.660, \\
p<.001\end{array}$ & $13(72 \%)$ & $53(22 \%)$ & $\begin{array}{l}X^{2}(1)=23.421, \\
p<.001\end{array}$ \\
\hline
\end{tabular}

\subsubsection{Online partner violence and sending / receiving of sexual images}

A similar pattern to that described for face-to-face violence was also found for experiences of online violence and sending sexual images across all countries (see table 12). Both girls and boys were around twice as likely to send sexual images if they had experienced online partner violence. The only exception was Cyprus where the relationship was not significant for females sending sexual images. Again, similar rates were found for receiving sexual images. Overall, the incidence rates for experiencing both online and offline forms of violence were highly correlated (see Barter et al., 2015) and consequently the similarities found in relation to the sending of images reflect this close association. Both experiences of online and offline violence increased the young person's likelihood of sending and receiving sexual images.

Table 12: Proportion who were victims of online IPV who had sent a sexual image

\begin{tabular}{|c|c|c|c|c|c|c|}
\hline & Female & & & Male & & \\
\hline & $\begin{array}{l}\text { Victim of } \\
\text { online } \\
\text { violence }\end{array}$ & $\begin{array}{l}\text { Not } \\
\text { victim of } \\
\text { online } \\
\text { violence }\end{array}$ & Chi square & $\begin{array}{l}\text { Victim of } \\
\text { online } \\
\text { violence }\end{array}$ & $\begin{array}{l}\text { Not victim } \\
\text { of online } \\
\text { violence }\end{array}$ & Chi square \\
\hline Bulgaria & 52 (36\%) & 28 (17\%) & $\begin{array}{l}X^{2}(1)=14.753 \\
p<.001\end{array}$ & 62 (46\%) & 31 (17\%) & $\begin{array}{l}X^{2}(1)=32.543, \\
p<.001\end{array}$ \\
\hline Cyprus & $9(8 \%)$ & $6(4 \%)$ & $\begin{array}{l}\text { Not } \\
\text { significant }\end{array}$ & $19(20 \%)$ & $14(11 \%)$ & Not significant \\
\hline
\end{tabular}




\begin{tabular}{|c|c|c|c|c|c|c|}
\hline England & $\begin{array}{l}124 \\
(65 \%)\end{array}$ & $50(24 \%)$ & $\begin{array}{l}X^{2}(1)=15.476 \\
, p<.001\end{array}$ & $39(50 \%)$ & $61(26 \%)$ & $\begin{array}{l}X^{2}(1)=15.476, \\
p<.001\end{array}$ \\
\hline Italy & $26(23 \%)$ & $21(12 \%)$ & $\begin{array}{l}X^{2}(1)=5.68 \\
P<.05\end{array}$ & 93 (37\%) & $46(15 \%)$ & $\begin{array}{l}X^{2}(1)=33.551, \\
p<.001\end{array}$ \\
\hline Norway & 60 (59\%) & $30(18 \%)$ & $\begin{array}{l}x^{2}(1)=49.361 \\
, p<.001\end{array}$ & $29(57 \%)$ & $36(17 \%)$ & $\begin{array}{l}X^{2}(1)=34.353, \\
p<.001\end{array}$ \\
\hline
\end{tabular}

\subsubsection{Sexual Partner Violence and sending/receiving of sexual images}

In all countries except Cyprus, where the numbers were too low to report findings, girls who had been a victim of sexual violence (forced or pressured) were significantly more likely to have sent a sexual image than those who had not been victims of sexual violence (see table 13). A similar pattern was also evident for male victims of sexual violence, although these findings need to be approached with caution as a proportion of male victims of sexual violence in some countries reported an affirmative only impact to their experiences. Also a high proportion of the boys who reported being victims of sexual violence also reported being perpetrators of sexual violence. This raises questions as to the interpretation and meaning of sexual coercion within some contexts (Barter et al., 2015).

Table 13: Proportions who were victims of sexual IPV who had sent a sexual image

\begin{tabular}{|c|c|c|c|c|c|c|}
\hline & Female & & & Male & & \\
\hline & $\begin{array}{l}\text { Victim of } \\
\text { sexual } \\
\text { violence }\end{array}$ & $\begin{array}{l}\text { Not } \\
\text { victim of } \\
\text { sexual } \\
\text { violence }\end{array}$ & Chi square & $\begin{array}{l}\text { Victim of } \\
\text { sexual } \\
\text { violence }\end{array}$ & $\begin{array}{l}\text { Not } \\
\text { victim of } \\
\text { sexual } \\
\text { violence }\end{array}$ & Chi square \\
\hline Bulgaria & 35 (55\%) & $44(18 \%)$ & $\begin{array}{l}X^{2}(1)=35.470, \\
p<.001\end{array}$ & $46(58 \%)$ & 46 (19\%) & $\begin{array}{l}X^{2}(1)=42.432, \\
p<.001\end{array}$ \\
\hline Cyprus & $\mathrm{n}<5$ & $13(6 \%)$ & $\begin{array}{l}\text { Expected cell } \\
\text { counts too } \\
\text { low }\end{array}$ & 32 (24\%) & $23(13 \%)$ & $\begin{array}{l}\text { Not } \\
\text { significant }\end{array}$ \\
\hline England & $\begin{array}{l}109 \\
(68 \%)\end{array}$ & $65(28 \%)$ & $\begin{array}{l}X^{2}(1)=62.191, \\
p<.001\end{array}$ & 31 (69\%) & $69(25 \%)$ & $\begin{array}{l}X^{2}(1)=34.308, \\
p<.001\end{array}$ \\
\hline Italy & $29(28 \%)$ & 17 (9\%) & $\begin{array}{l}X^{2}(1)=18.626, \\
p<.001\end{array}$ & $78(36 \%)$ & $61(18 \%)$ & $\begin{array}{l}X^{2}(1)=23.159, \\
p<.001\end{array}$ \\
\hline
\end{tabular}




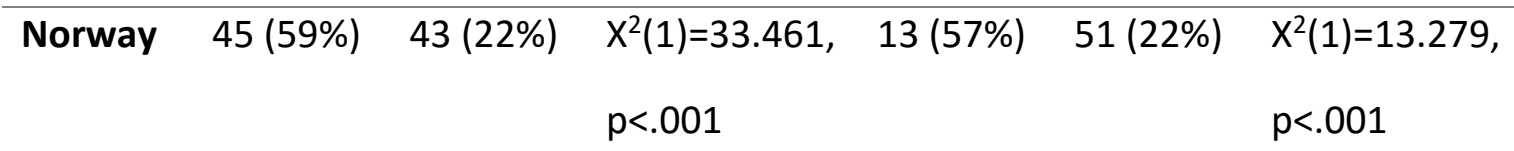

\section{Discussion}

This article has explored young people's reports of sexting within their intimate relationships in sample populations across five countries in Europe - two northern European countries (England and Norway) and three southern European countries (Cyprus, Bulgaria and Italy). As our research only explored the incidence and impact of sending or receiving sexual images in interpersonal partner relationships it cannot be directly compared to other research which reports sending sexual images in a wider context both in and outside of relationships. However, despite our more limited parameters, in most countries we have found a higher incidence of sexual image sending or receiving than found in previous European research with young people (Livingstone et al, 2011). Perhaps this is not so surprising given that sexts are commonly sent to desired or actual romantic and/or sexual partners (Lippman and Campbell 2014; Drouin and Landgraff, 2012).This may also reflect a more recent rise in sexting amongst young people and differences in the research methodologies used (Ringrose et al 2012). For example, the EU Kids online survey (Livingstone et al, 2011) involved interviews and questionnaire completion within the family home in contrast to the STIR study where surveys were undertaken in schools. In addition to this, the EU kids online survey included only images sent over the internet, and not images sent by mobile phone.

However, what is clear from our findings is that sexting is occurring to a considerable extent in young people's relationships and that rates increase as they progress through adolescence, as previous studies have also identified (Lippman and Campbell 2005). This resonates with findings on young adults (Drouin et al, 2015) which generally show higher rates of sexting. Our data showed that sexting rates varied within the different countries; with a much lower proportion of young people in Cyprus sexting and higher proportions in the more Northern European countries (England and Norway). It is not entirely clear as to why fewer young people in Cyprus are sexting. The use of smart phones in Cyprus is more recent than in other countries so it may be that they are in a 'catch up' period (Laouris \& Aristodemou, 2014). Other possible explanations include heightened fears around reputations due to the existence of smaller, closer knit communities and different attitudes towards the conduct / representation of females in society (Christou, 2012). It is also possible that young people are more fearful of admitting to sexting in countries with more traditional gender values (see FRA 2014). Conversely, higher rates may be reported in England and Norway where it is generally more acceptable for young women to be open 
about their engagement in sexual activities (Bozrm and Kontula, 2014), although even within England and Norway, this will vary across local and ethnic cultures.

Nevertheless, despite these caveats and country differences, our research found that the majority of young people in our samples, irrespective of gender or age, did not report engaging in sexting in their intimate relationships. This somewhat dispels the media presumption that sexting is now a routine aspects of young people's 'flirting' strategies and relationship cultures. This sexting presumption can influence both adults and young people's perceptions of how normalised a behaviour is (Lippman and Campbell, 2014). Lapiniski and Rimal (2005) note that the gulf between collective norms compared to actual behaviours is greatest in relation to intimate activities.

This finding has implications for interventions. The Social Norms Approach (SNA) assumes that people have mistaken perceptions of the attitudes and behaviour of others (Berkowitz 2004). Prevalence of 'risky' behaviours, especially sexual behaviours, are often overestimated. This affects individual behaviour in two ways: by justifying and increasing prevalence of 'risky' behaviour, and by increasing the likelihood of an individual remaining silent about any discomfort caused by such behaviour (thereby reinforcing social tolerance). As Walrave et al (2015) report that the subjective norm is the strongest predictor of young people's sexting intention, ilnterventions need to challenge the presumed, and media driven, norm that the vast majority of young people are engaged in sexting and thereby seek to alter what is considered the collective norm. We are not aligning sexting with risk in any simplistic manner, however we do need to ensure that young people are making informed decisions free from false assumptions.

A key aim of our research was to explore the impact of sexting in order to provide a more nuanced understanding of young people's experiences. Our findings show a mixed picture. We acknowledge that our impact measures contained more negative outcomes, due to the need for consistency across the survey measure. However, despite this potential bias, we still found that that sexting was generally (over $50 \%$ ) associated with positive only impacts, (Lippman and Campbell 2014, Cox 2009, Mitchell et al 2012, Lee and Croft 2015) except for girls in England where outcomes were more varied. Male participants overwhelmingly reported positive impacts. This has major implications regarding how sexting should be conceptualised. Our findings show that, for many girls and the majority of boys, sexting was a positive and mainly reciprocal experience. Consequently, approaches that problematize the sending of all sexual images may risk alienating many young people, including those seeking support if things do go wrong, primarily girls and young women (Willard, 2010). As Ringrose et al (2012) point out, sexting, unlike bullying, cannot simply be viewed as a problem. Evidence has shown that interventions to reduce negative behaviours in youth based on a risk and consequence approach generally fail to reduce unhealthy behaviour (Zirkel 2009). Accordingly, professionals working with young people around their developing sexuality need to include open discussions and activities to explore with young 
people's sexual ideas and desires embedded within a respectful relationship agenda, which may or may not also include the exchange of sexual images.

However, our findings clearly show that not all sexting was undertaken within these parameters. In England, Italy and Norway, around half of girls reported a negative impact after sending a sexual image. In fact twice as many girls compared to boys in these country samples reported a negative impact, demonstrating that the experience of sending sexual images is indeed gendered (Lippman and Campbell, 2014; Ringrose et al., 2012). Our data shows that, in England and Norway, the sharing of sexual images by partners may have a strong influence over the negative sentiments associated with sending sexual images for girls. However, this did not explain the negative feelings for girls in Italy where very few reported that images were shared.

We sought to unpack some of these gendered discrepancies by looking more closely at the relationship context in which these activities were embedded by examining the possible associations between young people's experiences of sending sexual images and IPVA. In all countries, it was evident that those who reported experiencing some form of IPVA were at least twice as likely to have sent or received a sexual image as those who were not victimised. This association held for both face-to-face and online forms of IPVA. We also found that over a quarter of girls in England who had sent a sexual image had been pressured by a partner to do so and almost a half had done so to prove their commitment. Similarly, previous research identifies that girls are no more likely (Lippman and Campbell 2014; Lenhart, 2009) or only slightly more likely (MTV Associated Press, 2009) to send sexual images than boys however, they were more likely to experience pressure to do so (Lippman and Campbell, 2014). Our study therefore implies that young women in relationships characterised by abusive behaviour may be more likely to report pressured sexting activities and attribute a negative impact.

We also identified that when images were shared, irrespective of the relationships context, girls routinely recorded a negative responses. Few boys reported this; sharing was viewed as a predominantly affirmative experience. Reflecting previous findings (Ringrose et al., 2012) our study confirms that the sexual double standard predominates as it is girls' reputations which are scrutinised and it is girls who primarily suffer the consequences of their partner's actions. Previous commentators have argued that, despite gender neutrality in sexting rates, it is images involving adolescent girls that have dominated both the arguments and anxieties around this issue (Lippman and Campbell, 2014; Draper, 2012). However, possibly this is because as we have shown, and others have identified, impacts are highly gendered. Consequently, unless the social and cultural heteronormative expectations which perpetuate and reinforce gendered sexual double standards are challenged, we will inevitably fail to address the detrimental impacts associated with sexting and may 
inadvertently place the responsibility and associated blame on girls for sending the image rather than on those who have perpetrated the harm.

\section{Conclusion}

Our research findings indicate that boys can exploit the unequal way that girls are viewed in society in relation to their sexuality by sharing sexual images of their partners. We identified that many more young people who reported experiencing IPVA also reported increased rates for sending sexual images, suggesting some level of coercion may be a factor.

However, as stated in the introduction, we should be cautious in our assumptions that these behaviours constitute coercive control as defined by Stark. We therefore need to understand more about the reasons why boys share images of their partners - as revenge (Morris, 2014) - or to achieve status for themselves (Ringrose et al., 2012), or due to peer pressure. Irrespective of the reasons, the negative outcomes for their partners remains the same. Our research clearly shows that we need to view sexting within a broader context of healthy relationship education (Ringrose et al., 2012) which has proved successful with regard to young people's attitudinal change towards domestic violence (Fox et al., 2014; Gadd et al., 2014) and in some instances secured long-term behavioural change (Wolfe et al 2009). We know that healthy relationship interventions which address gender inequalities are most effective (Stanley et al., 2015), these programmes now need to incorporate a gendered understanding of sexting whilst ensuring that this is embedded within a positive construction of young sexual exploration.

\section{References}

Aghtaie, N. (2015). Iranian Women's Perspectives on Violence against Women in Iran and the UK. Iranian Studies, (ahead-of-print), 1-19.

Albury, K., Funnell, N., \& Noonan, E. (2010, July). The politics of sexting: young people, self representation and citizenship. In Published in proceedings of the Australian and New Zealand Communication Association Conference: Media, Democracy and Change, Old Parliament House.

Albury, K., \& Crawford, K. (2012). Sexting, consent and young people's ethics: Beyond Megan's Story. Continuum, 26(3), 463-473.

Associated Press and MTV (2009). MTV Digital Abuse Survey, Executive Summary. Retrieved on $27^{\text {th }}$ October, 2015 , from.

http://surveys.ap.org/data/KnowledgeNetworks/AP_Digital_Abuse_Topline_092209.pdf

Arcabascio, C. (2010) 'OMG RU Going to Jail???'. Richmond Journal of Law and Technology, $\mathrm{XVI}(3): 1-43$.

Barter, C., McCarry, M., Berridge, D., \& Evans, K. (2009). Partner exploitation and violence in teenage intimate relationships. London: NSPCC. 
Barter, C., Stanley, N., Wood, M., Aghtaie, N., Larkins, C., Øverlien, C., Hellevik, P., De Luca, N., Cappello, G., Shahbazyan, L., Lesta, S. (2015). Safeguarding Teenage Intimate Relationships (STIR): Connecting online and offline contexts and risks. Research Report. Retrieved 27/10/15 from: http://stiritup.eu/wp-content/uploads/2015/06/STIR-ExecSummary-English.pdf

Berkowitz, A. D. (2004). The social norms approach: Theory, research and annotated bibliography. Higher Education Center for Alcohol and Other Drug Abuse and Violence Prevention. US Department of Education.

Bozrm, M., \& Kontula, O. (2014). Sexual initiation and gender in Europe: A cross-cultural analysis of trends in the twentieth century. In Sexual behaviour and HIV/AIDS in Europe: comparisons of national surveys, 37.

Cox Communications (2009). Teen online and wireless safety survey: Cyberbullying, sexting, and parental controls. Retrieved on 22/5/15, from. http://www.cox.com/wcm/en/aboutus/datasheet/takecharge/2009-teensurvey.pdf?campcode=takecharge-research-link_2009-teen-survey_0511

Coy, M. (2013) Children, childhood and sexualised popular culture in Wild, J. (ed) Exploiting Childhood London: Jessica Kingsley

Corsaro, W. (2014) The Socilogy of Childhood $4^{\text {th }}$ edition. Sage.

Christou, G. (2012). Understanding gender-based violence among adolescents: Exposing challenges for an inclusive educational policy and citizenship education in Cyprus. Citizenship Teaching \& Learning, 8(1), 75-90.

Crofts, T., Lee, M., McGovern, A., Milivojevic, S. (2015) Sexting and Young People. Palgrave Macmillan.

Döring, N. (2014). Consensual sexting among adolescents: Risk prevention through abstinence education or safer sexting?. Cyberpsychology, 8(1), 1-18.

Draper, N. R. (2012). Is your teen at risk? Discourses of adolescent sexting in United States television news. Journal of Children and Media, 6(2), 221-236.

Drouin, M., \& Landgraff, C. (2012). Texting, sexting, and attachment in college students' romantic relationships. Computers in Human Behaviour, 28, 444-449.

Drouin, M., Ross, J., \& Tobin, E. (2015). Sexting: A new, digital vehicle for intimate partner aggression?. Computers in Human Behavior, 50, 197-204.

Egan, D. and Hawkes, G. (2010). Theorizing the Sexual Child on Modernity. New York. Palgrave Macmillan. 
EIGE (European Institute for Gender Equity) (2013) Gender Equality Index: Main Findings. Retrieved 27.10.15 from.

http://eige.europa.eu/content/document/gender-equality-index-main-findings

Ferro, M 92010) Sexting: the "perfect storm" of evolution, culture, and technology (some thoughts), The Science Creative Quarterl, http://www.scq.ubc.ca/sexting-the-perfect-stormof-evolution-culture-and-technology-some-thoughts/

Fox, C. L., Corr, M. L., Gadd, D., \& Sim, J. (2014). Evaluating the effectiveness of domestic abuse prevention education: Are certain children more or less receptive to the messages conveyed?. Legal and Criminological Psychology. Online early view 30.1.14.

Fox , C. L., Corr, M. L., Gadd, D., \& Butler, I. (2013). Young teenagers' experiences of domestic abuse. Journal of Youth Studies, 17(4), pp.510-526.

Flood, M. (2008) Boys, sex and porn: New technologies and old dangers: Whatever happened to child sexual abuse?, BASPSCAN \& Nottingham Trent University Unit for Critical Studies in Men \& Masculinities, London.

FRA (European Union Agency for Fundamental Rights) (2014) Violence Against Women: An EU-Wide Survey.

http://fra.europa.eu/sites/default/files/fra-2014-vaw-survey-main-results_en.pdf

Gadd, D., Fox, C. L., \& Hale, R. (2014). Preliminary steps towards a more preventative approach to eliminating violence against women in Europe. European Journal of Criminology, 11(4), 464-480.

Galtung, Johan. (1990) "Cultural violence." Journal of peace research 27.3: 291-305.

Gámez-Guadix, M., Almendros, C., Borrajo, E., \& Calvete, E. (2015). Prevalence and Association of Sexting and Online Sexual Victimization Among Spanish Adults. Sexuality Research and Social Policy, 12(2), 145-154.

Hand, T., Chung, D. \& Peters, M. 2009, 'The use of information and communication technologies to coerce and control in domestic violence and following separation', Stakeholder Paper 6, Australian Domestic \& Family Violence Clearinghouse, Canberra.

Hinduja, S., \& Patchin, J. W. (2010). Sexting: A brief guide for educators and parents [fact sheet]. Retrieved 21/05/2015, from. http://pershingpto.org/files/2014/04/Sexting-FactSheet.pdf

Holland, S. (1998) The Male in the Head: Young People, Heterosexuality and Power. London: Tufnell Press. 
Houck, C. D., Barker, D., Rizzo, C., Hancock, E., Norton, A., \& Brown, L. K. (2014). Sexting and sexual behavior in at-risk adolescents. Pediatrics, 133(2), e276-e282.

Kee, J. 2005, 'Cultivating violence through technology: Exploring the connections between information and communication technologies (ICT) and violence against women (VAW)', APC WNSP Issues Paper, retrieved from, <http://www.genderit.org/content/cultivatingviolencethrough-technology-exploring-connections-between-internet-communication>.

Klettke, B., Hallford, D.J., Mellor, D.J. (2014) Sexting prevalence and correlates: a systematic literature review. Clinical Psychology Review, 34 (1): 44-53.

Laouris, Y., \& Aristodemou, E. (2014). Risks and safety for children on the internet: the Cyprus report: full findings from the EU Kids Online survey of Cypriot 9-16 year olds and their parents. EU Kids Online, LSE.

Lapinski, M. K., \& Rimal, R. N. (2005). An explication of social norms. Communication Theory, 15(2), 127-147.

Leadbeater, B. J., Banister, E. M., Ellis, W. E., \& Yeung, R. (2008). Victimization and relational aggression in adolescent romantic relationships: The influence of parental and peer behaviours, and individual adjustment. Journal of Youth and Adolescence, 37(3), 359-372.

Lenhart, A. (2009). Teens and Sexting: How and why minor teens are sending sexually suggestive nude or nearly nude images via text. Washington, DC: Pew Internet \& American Life Project. Retrieved 22/05/2015 from http://www.pewinternet.org/Reports/2009/Teensand-Sexting.aspx

Lee, M., Crofts, T., Salter, M., Milivojevic, S., \& McGovern, A. (2013). "Let's Get Sexting": Risk, Power, Sex and Criminalisation in the Moral Domain'. International Journal for Crime, Justice and Social Democracy, 2(1), 35-49.

Lee, M., \& Crofts, T. (2015). Gender, Pressure, Coercion and Pleasure: Untangling Motivations for Sexting Between Young People. British Journal of Criminology, azu075.

Lounsbury, K., Mitchell, K. J., \& Finkerhor, D. (2011). The true prevalence of sexting. Retrieved on 22/05/2015 from. http://www.unh.edu/ccrc/pdf/Sexting\%20Fact\%20Sheet\%204_29_11.pdf

Lippman, J. R., \& Campbell, S. W. (2014). Damned if you do, damned if you don't... if you're a girl: Relational and normative contexts of adolescent sexting in the United States. Journal of Children and Media, 8(4), 371-386.

Livingstone, S. and Helsper, E. (2009) 'Balancing opportunities and risks in teenagers' use of the internet: the role of online skills and internet self-efficacy'. New Media and Society. 12 (2): 309-329. 
Livingstone, S. Haddon, L. Görzig, A., Olafsson, K. and with members of the EU Kids Online Network (2011) Risks and safety on the internet: The perspectives of European children: Full findings and policy implications from the EU Kids Online survey of 9-16 year olds and their parents in 25 countires. London School of Economics and Political Science.

Livingstone, S., \& Görzig, A. (2012). Sexting: the exchange of sexual messages online among European youth. Policy Press.

Mitchell, K. J., Finkerhor, D., Jones, L. M., \& Wolak, J. (2012). Prevalence and characteristics of youth sexting: A national study. Paediatrics, 129, 13-20.

Morris, E. (2014) 'Sexting: Felony or Flirting?' Family Online Safety Institute. Retrieved 7/5/2015 from https://fosi.org/policy-research/sexting-felony-or-flirting/.

Muscari, M. E. (2009). Sexting: New technology, old problem. Medscape Public Health \& Prevention.

OED Online. (2015) "sexting, n." OED Online. Oxford University Press, June 2015. Web. 7 September 2015.

Powell, A. 2009, 'New technologies, unauthorised visual images and sexual assault', ACSSA Aware, n.23, pp.6-12.

Radford, L., Corral, S., Bradley. C., Fisher, H., Bassett, C., Howat, N., and Collishaw, S. (2011) Child abuse and neglect in the UK today. London: NSPCC.

Renold, E. (2005) Girls, Boys, and Junior Sexualities: Exploring Children's Gender and Sexual Relations in the Primary School, Psychology Press.

Renold, E., \& Ringrose, J. (2011). Schizoid subjectivities? Re-theorizing teen girls' sexual cultures in an era of 'sexualisation'. Journal of Sociology, 47(4), 389-409.

Renold, E., Ringrose, J., Egan,. (2015) Children, Sexulaity and Sexulaisation. Palgrave Macmillan.

Rice, E. Rhoades, H., Winetrobe, H. Sanchez, M., Montroya, J. Plant, A. Kordic, T. (2012). Sexually Explicit Cell Phone Messaging Associated With Sexual Risk Among Adolescents. Paediatrics. 130 (4): 667-674.

Ringrose, J. and Barajas, K.E. (2011) Gendered risks and opportunities? Exploring teen girls' digital sexual identity in postfeminist media contexts, International Journal of Media and Cultural Politics, Special Issue: Post feminism and the Mediation of Sex, 7(2): 121-138.

Ringrose, J. Gill, R. Livingstone, S. and Harvey, L. (2012) A Qualitative Study of Children, Young People and Sexting. London. NSPCC. 
Ringrose, J., Harvey, L., Gill, R., Livingstone, S. (2013) Teen girls, sexual double standards and 'sexting': Gendered value in digital image exchange. Feminist Theory 14 (3) 305-323.

Ringrose, J., \& Harvey, L. (2015). Boobs, back-off, six packs and bits: Mediated body parts, gendered reward, and sexual shame in teens' sexting images. Continuum, 29(2), 205-217.

Sacco, D. T.,Argudin, R. Maguire, J. Tallon, K. (2010) Sexting: Youth Practices and Legal Implications. Berker Centre Research Publication No. 2010-8. Cambridge, MA: Berkman Center for Internet and Society.

Safer Internet Centre (Accessed 07/05/2015) Sexting: Online Issues for Parents and Carers. Downloaded from http://www.saferinternet.org/online-issues/parents-and-carers/sexting on $07 / 05 / 2015$.

Schmitz, S., and Siry, L. (2011) "Teenage Folly or Child Abuse? State Responses to"Sexting" by Minors in the U.S. and Germany," Policy \& Internet: Vol. 3: Iss. 2,

Smith, S. (2012) Study of Self-Generated Sexually Explicit Images and Videos Featuring Young People Online. Internet Watch Foundation.

Stanley, N. Ellis, J., Farrelly, N., Hollinghurst, S., Bailey, S. and Downe, S. (2015) Preventing Domestic Abuse for Children and Young People (PEACH): A Mixed Knowledge Scoping Review. Public Health Res. http://www.journalslibrary.nihr.ac.uk/phr

Stark, E. (2007). Coercive control: How men entrap women in personal life. Oxford University Press.

Temple, J. R., Paul, J. A., van den Berg, P., Le, V. D., McElhany, A., \& Temple, B. W. (2012). Teen sexting and its associations with sexual behaviours. Archives of Paediatrics and Adolescent Medicine, 166, 828-833.

Tolman, D. L. (2012) Female Adolescents, Sexual Empowerment and Desire: A missing Discourse of Gender Inequity?. Sex roles, 66 (11-12): 746-757.

The National Campaign to Prevent Teen and Unplanned Pregnancy, CosmoGirl.com (2008): Results From a Survey of Teens and Young Adults. Washington. DC. The National Campaign to Prevent Teen and Unplanned Pregnancy and CosmoGirl.com.

Walrave, M., Ponnet, K., Van Ouytsel, J., Van Gool, E., Heirman, W., \& Verbeek, A. (2015). Whether or not to engage in sexting: Explaining adolescent sexting behaviour by applying the prototype willingness model. Telematics and Informatics, 32(4), 796-808.

Willard, N. E. (2010). Sexting and youth: Achieving a rational response. Journal of Social Sciences, 6(4), 542-562. 
Wolak, J. \& Finkelhor, D. 2011, Sexting: A typology, Crimes Against Children Research Center,University of New Hampshire, New Hampshire.

Wolfe, D., Crooks, C., Jaffe, P., Chiodo, D., Hughes, R., Ellis, W., Stitt, L. and Donner, A.(2009) A school-based program to prevent adolescent dating violence: a cluster randomized Trial, Archives of Pediatric and Adolescent Medicine. 163, 8: pp.692-9.

Wood, M., Barter, C., \& Berridge, D. (2011). Standing on My Own two Feet: Disadvantaged Teenagers, Intimate Partner Violence and Coercive Control. London: NSPCC.

Ybarra, M. L., \& Mitchell, K. J. (2014). "Sexting" and Its Relation to Sexual Activity and Sexual Risk Behavior in a National Survey of Adolescents. Journal of Adolescent Health, 55(6), 757764.

Zirkel, P. A. (2009). All a Twitter about sexting. Phi Delta Kappan, 91(2), 76-77. 